\title{
Performance of schizophrenic patients in the Stroop Color Word Test and electrodermal responsiveness after acute administration of cannabidiol (CBD)
}

\section{Desempenho de pacientes esquizofrênicos no Stroop Color Word Test e responsividade eletrodérmica após administração aguda de canabidiol (CBD)}

\author{
Jaime E. C. Hallak, ${ }^{1,2}$ João Paulo Machado-de-Sousa, ${ }^{1,2}$ José Alexandre S. Crippa, ${ }^{1,2}$ \\ Rafael Faria Sanches, ${ }^{1,2}$ Clarissa Trzesniak, ${ }^{1,2}$ Cristiano Chaves, ${ }^{1,2}$ Sandra Aparecida Bernardo, ${ }^{1}$ Simone Cecílio \\ Regalo, ${ }^{2,3}$ Antonio Waldo Zuardi ${ }^{1,2}$ \\ ${ }^{1}$ University Hospital of the Ribeirão Preto Medical School, Department of Neuroscience and Behavior, Universidade de São Paulo (USP), \\ Ribeirão Preto (SP), Brazil \\ ${ }^{2}$ Instituto Nacional de Ciência e Tecnologia - Translacional em Medicina (CNPq) \\ ${ }^{3}$ Dentistry School of Ribeirão Preto, Department of Morphology, Stomatology and Physiology, Universidade de São Paulo (USP), Ribeirão \\ Preto (SP), Brazil
}

\begin{abstract}
Objective: The last decade has seen increasing evidence of dysfunctions in the endogenous cannabinoid system in schizophrenia and of its relationship with the typical cognitive impairment of the disorder. Studies in animal models, healthy volunteers, and psychotic patients clearly suggest an antipsychotic-like effect of cannabidiol. This study investigated the effects of cannabidiol on selective attention in 28 schizophrenic patients using the Stroop Color Word Test and on these patients' electrodermal responsiveness to auditive stimuli. Method: The subjects attended two experimental sessions, the first one without the administration of drugs. In the second session the subjects were divided into three groups that received either a single dose of cannabidiol $300 \mathrm{mg}$ or cannabidiol $600 \mathrm{mg}$ or placebo. Results: The three groups did not differ significantly with respect to electrodermal measures in the two experimental sessions. When the first and second sessions were compared improved performance was found in all three groups, with patients who received placebo and cannabidiol $300 \mathrm{mg}$ performing better than those who received cannabidiol $600 \mathrm{mg}$. Conclusion: The single, acute administration of cannabidiol seems to have no beneficial effects on the performance of schizophrenic patients in the Stroop Color Word Test, although the hypothesis that chronic administration may lead to improvement cannot be disregarded.
\end{abstract}

Descriptors: Schizophrenia; Cognition; Cannabidiol; Psychotic disorders

\section{Resumo}

Objetivo: Descobertas relativas a possiveis disfunçôes do sistema canabinóide endógeno na esquizofrenia e sua relação com o prejuizo cognitivo característico da doença têm aumentado durante a última década. Estudos com modelos animais, voluntários saudáveis e pacientes psicóticos sugerem claramente que o canabidiol possui efeitos antipsicóticos. Este estudo investigou os efeitos do canabidiol sobre a atenção seletiva por meio do Stroop Color Word Test $e$ a responsividade eletrodérmica a estímulos auditivos em 28 pacientes com esquizofrenia. Método: Duas sessóes experimentais foram realizadas, a primeira sem a administração de drogas. Na segunda sessão, os sujeitos foram divididos em três grupos que receberam dose única de canabidiol $300 \mathrm{mg}$, canabidiol 600mg ou placebo. Resultados: Os três grupos não diferiram significativamente no que se refere às medidas eletrodérmicas nas duas sessöes experimentais. Os três grupos apresentaram melhora da primeira para a segunda avaliação, com os grupos placebo e canabidiol $300 \mathrm{mg}$ superiores ao grupo canabidiol 600mg. Conclusão: A administração aguda de canabidiol em dose única parece não ter efeitos benéficos sobre o desempenho de pacientes com esquizofrenia no Stroop Color Word Test, embora estes dados não sejam suficientes para refutar a hipótese de que a administraçāo continuada de canabidiol possa resultar em melhora no funcionamento cognitivo em esquizofrenia.

Descritores: Esquizofrenia; Cognição; Canabidiol; Transtornos psicóticos

\section{Introduction}

In the middle of the $19^{\text {th }}$ century, Moreau first employed marijuana as an experimental psychotomimetic substance. ${ }^{1}$ The discovery of cannabinoid receptors ${ }^{2}$ and endogenous ligands $s^{3}$
Submitted: March 30, 2009

Accepted: October 1, 2009
Correspondence

Jaime E. C. Hallak

Hospital das Clínicas da Faculdade de Medicina de Ribeirão Preto - USP Av. dos Bandeirantes, 3900, $3^{\circ}$ andar

14048-900 Ribeirão Preto, SP, Brazil

Tel.: (+55 16) 3602-2853 Fax: (+55 16) 3602-2703

E-mail: jhallak@fmrp.usp.br 
(anandamide - palmityl ethanolamide, 2-arachidonyl glycerol) supported the notion of a central neuromodulatory cannabinoid system, and there seems to exist a complete system with multiple cannabinoid receptors and anandamide-related compounds. ${ }^{4}$

There is evidence suggesting an association between Cannabis and psychosis or schizophrenia: the use of marijuana is more prevalent among patients with schizophrenia as compared to the healthy population; ${ }^{5}$ the extended use of marijuana can trigger psychotic episodes in schizophrenic patients; ${ }^{6}$ and increased anandamide levels have been found in the liquor of schizophrenic patients as compared with healthy controls. ${ }^{7}$ Additionally, cannabinoid agonists impair many cognitive functions (especially memory and attention) and similarities have been reported between the cognitive impairment seen in schizophrenia and that provoked by intoxication with Cannabis. ${ }^{8,9}$ Consistent with a potential contribution of the cannabinoid system to the physiopathology of schizophrenia, the highest densities of cannabinoid receptors are found in brain regions reported to be implicated in schizophrenia, including the PFC, basal ganglia, hippocampus, and anterior cingulate cortex. ${ }^{9}$ The association between cannabis and psychosis could be understood both as a hyperfunctioning of the endocannabinoid system and as an attempt to overcome a possible functional deficit of this system in patients with psychosis.

Scientific evidence gives support to attempts at testing cannabinoid antagonists as a possible therapeutic strategy for the treatment of psychiatric disorders. ${ }^{10}$

Since the 1970s, pioneering studies on CBD effects have been conducted in Brazil. ${ }^{11,12}$ Many of these studies have suggested that Cannabidiol (CBD), a cannabinoid devoid of the typical psychological effects of cannabis in humans, ${ }^{12}$ acts as an antagonist of the effects of $\triangle 9$-THC when administered simultaneously. ${ }^{12,13}$ The study involving healthy volunteers suggested that CBD reduces both the anxiety and the psychotomimetic effects of $\triangle 9$-THC, leading to the proposition that this effect is due to an action of CBD itself. ${ }^{12}$

The antipsychotic-like properties of CBD have been investigated in animal models using behavioral and neurochemical techniques which suggested that CBD has a pharmacological profile similar to that of atypical antipsychotic drugs. ${ }^{14}$ The results of two studies on healthy volunteers using perception of binocular depth inversion and ketamine-induced psychotic symptoms supported the proposal of the antipsychotic-like properties of CBD. ${ }^{15,16}$ In addition, open case reports of schizophrenic patients treated with $\mathrm{CBD}^{17}$ and a preliminary report of a controlled clinical trial comparing $\mathrm{CBD}$ with an atypical antipsychotic $\mathrm{drug}^{18}$ have confirmed that this cannabinoid can be a safe and well-tolerated alternative treatment for schizophrenia.

CBD increased c-Fos expression in many brain areas including the medial PFC and the cingulate gyrus, ${ }^{19}$ suggesting increased activity in these regions. Previous reports propose that these areas are involved in attentional processes, frequently impaired in schizophrenia. ${ }^{20}$ The cognitive impairments, mainly in attention, working memory, and aspects of executive function, are mostly associated with the long-term disability typically produced by the disorder, and the currently available treatments have limited efficacy against them. ${ }^{21,22}$ Since CBD increases the activity in areas related to attention, our hypothesis is that this cannabinoid could act by improving selective attention.

Selective attention can be assessed using the Stroop Color Word Test (SCWT) ${ }^{23}$ and is frequently associated with skin conductance responsiveness. ${ }^{24} \mathrm{~A}$ deficit in selective attention indicated by a higher number of errors in the SCWT is associated with low electrodermal responsiveness in schizophrenia patients. ${ }^{25}$

The objective of this study was to assess the performance of patients with schizophrenia in the SCWT under the influence of a single oral dose of $\mathrm{CBD}$ and verify whether this influence is associated with electrodermal responsiveness.

\section{Method}

\section{Subjects}

The sample consisted of 28 (18 male) outpatients with schizophrenia recruited at the university hospital of the Ribeirão Preto Medical School and from the city's mental health outpatient clinic. Patients were more than 18 years of age and had at least four years of education, as well as a diagnosis of schizophrenia confirmed with the clinical interview ${ }^{26}$ for DSM-IV (SCID-CV) and score $<2$ for each item of the Brief Psychiatric Rating Scale $(\mathrm{BPRS})^{27}$ in order to avoid the inclusion of patients during an acute psychotic episode. Patients with any clinical conditions other than schizophrenia, under psychotropic medication different from the prescribed antipsychotic, pregnancy or suspected pregnancy, history of adverse reactions to marijuana, and previous history of substance abuse were not included in the study.

The patients and their accompanying relatives were informed about the procedures and provided written consent to participate. The study protocol was approved by the local ethics committee (process HCRP 805/97).

\section{Psychiatric scales}

The SCID-CV was used to confirm the diagnosis at the time of enrollment. The BPRS and the Positive and Negative Symptoms Scale (PANSS) ${ }^{28}$ were used to assess symptom profiles in the experimental sessions.

\section{Stroop Color Word Test}

A version with two cards, instead of the three originally proposed, was used in the application of the SCWT, according to the procedure proposed by Liddle \& Morris. ${ }^{29}$ The first card (referred to as board I in the present study) contained 100 words (color names) printed in black, whereas the second card (board II) displayed 100 words describing color names and printed in colors different from their semantic meaning. The task consisted of reading the words on board I and naming the color of the ink of each word on board II. The time (seconds) taken to complete 
each board and the number of errors in reading and color naming were recorded, according to the method proposed elsewhere. ${ }^{30}$

\section{Skin conductance level}

Electrodermal measures were acquired through a computerized system for psychophysiological records (Contact Precision Instruments Inc., Boston - MA, USA) with constant voltage $(0.6 \mathrm{~V})$, automatic back-off system, and Beckman skin electrodes connected to the subjects' hand palm.

\section{Drugs}

CBD (kindly donated by Dr. R. Mechoulam from the University of Israel, Jerusalem), in doses of $300 \mathrm{mg}$ and $600 \mathrm{mg}$, and placebo (starch) were prepared in identical gelatin capsules.

\section{First experimental session}

The participants were instructed to arrive at the laboratory at 8 a.m. after having a standardized breakfast consisting of one glass of milk and a regular piece of bread.

After evaluation with the BPRS and PANSS, participants were submitted to skin conductance level recordings in a room with sound and light attenuation. The subjects were asked to remove watches and jewelry and to wash their hands. They were then placed in a comfortable, reclined armchair and the electrodes were connected to the right hand palm of right-handed subjects and to the left palm in left-handed ones. The electrodes were attached by $1 \mathrm{~cm}$-wide adhesive tape and the contact was ensured by filling the gap between the electrodes and the skin with conductive paste (KY gel, Johnson \& Johnson). The following instructions were then given to the subjects: "Try to relax, stay seated and avoid moving your hand. You will hear some sounds at different intervals. Try to ignore them, keep your eyes open and do not sleep. The experiment will last approximately 15 minutes. Please wait until I come back to take the electrodes off." The subjects put on their earphones and were observed from the control room through a unidirectional mirror.

After a 5-minute habituation period during which the volunteers remained silent, the stimulation period started, lasting for a subsequent 10 minutes. During this period, ten $80 \mathrm{~dB}$ tones with one-second duration were presented in a frequency of $800 \mathrm{~Hz}$, at intervals ranging between 40 and 80 seconds in a pseudo-random order so that the volunteers could not predict the next stimulus.

Skin conductance orienting responses (SCORs) were regarded as those with fluctuations equal to or higher than $0.05 \mu \mathrm{S}$ occurring within a responsiveness window of between one and five seconds after stimulus presentation. The non-responsiveness criteria adopted was the strict one: no electrodermal response (SCOR) of at least $0.05 \mu \mathrm{S}$ to any stimuli presented. ${ }^{31,32}$

After skin conductance levels were recorded, the participants sat by a table to perform the SCWT. The volunteers' performance was recorded and independently evaluated afterwards by two skilled examiners.

\section{Second experimental session}

The participants were divided into three groups matched in terms of sex, years of education, age, and symptom profile (predominance of either negative or positive symptoms according to the scores of the BPRS and PANSS). The first and second groups would receive CBD $300 \mathrm{mg}$ and $600 \mathrm{mg}$, respectively, and the third would be given placebo in a double-blind procedure.

The second session took place with a minimum interval of one month after the first one. At the beginning of the session, the patients were again evaluated with the BPRS and PANSS in order to assess whether there had been any significant alteration in their psychopathological state. After this evaluation, the patients received one of the two CBD doses or placebo.

After a 60-minute period of free activities (drawing, reading, resting etc.), the participants were submitted to skin conductance level recordings and to the SCWT, in an identical procedure to that of the previous session.

\section{Statistical analysis}

Clinical and demographic characteristics of the three groups were compared by means of chi-square exact tests. BPRS and PANSS scores, time under antipsychotic treatment, and number of hospitalizations were compared by analysis of variance (ANOVA).

The comparison between the three groups in relation to skin conductance level, spontaneous fluctuations, and number of SCOR was performed with the nonparametric test of Kruskal-Wallis.

The time (seconds) spent to complete each board and the number of errors in the SCWT in the first and second sessions was analyzed using a multifactor ANOVA to examine the main effects of group (placebo, CBD-300 and CBD-600), sex, electrodermal response (responsive and non-responsive), and duration of disease ( $<5$ years or $>5$ years). Student's t-test for related samples was used to perform intra-group comparisons between sessions. The level of statistical significance was set at $\mathrm{p}<0.05$.

\section{Results}

The analysis of the clinical, demographic, and electrodermal responsiveness data showed no differences among the three groups (Table 1), which suggests that they were homogeneous.

In the first session the ANOVA showed significant SCWT effect only for the electrodermal response factor $\left(\mathrm{F}_{1,16}=5.98\right.$; $\mathrm{p}<$ $0.05)$ related to time taken to complete board I. The mean time required for the responsive group was $77.8(\mathrm{SEM}=11.7)$ and for the non-responsive it was was $119.7(\mathrm{SEM}=12.3)$.

In the second assessment, the ANOVA showed a significant effect for group factors related to the number of errors on board II $\left(F_{2,16}=6.027 ; \mathrm{p}=0.014\right)$. The group that received $\mathrm{CBD} 600 \mathrm{mg}$ had a higher score compared to the other two. The number of errors on board II in sessions I and II is presented in Figure 1.

A decrease in the number of errors was observed for the three groups in the second session, although this reduction was smaller in the CBD $600 \mathrm{mg}$ group and presented only a tendency to statistical significance. 
Table 1 - Clinical demographic and electrodermal characteristics of the three experimental groups

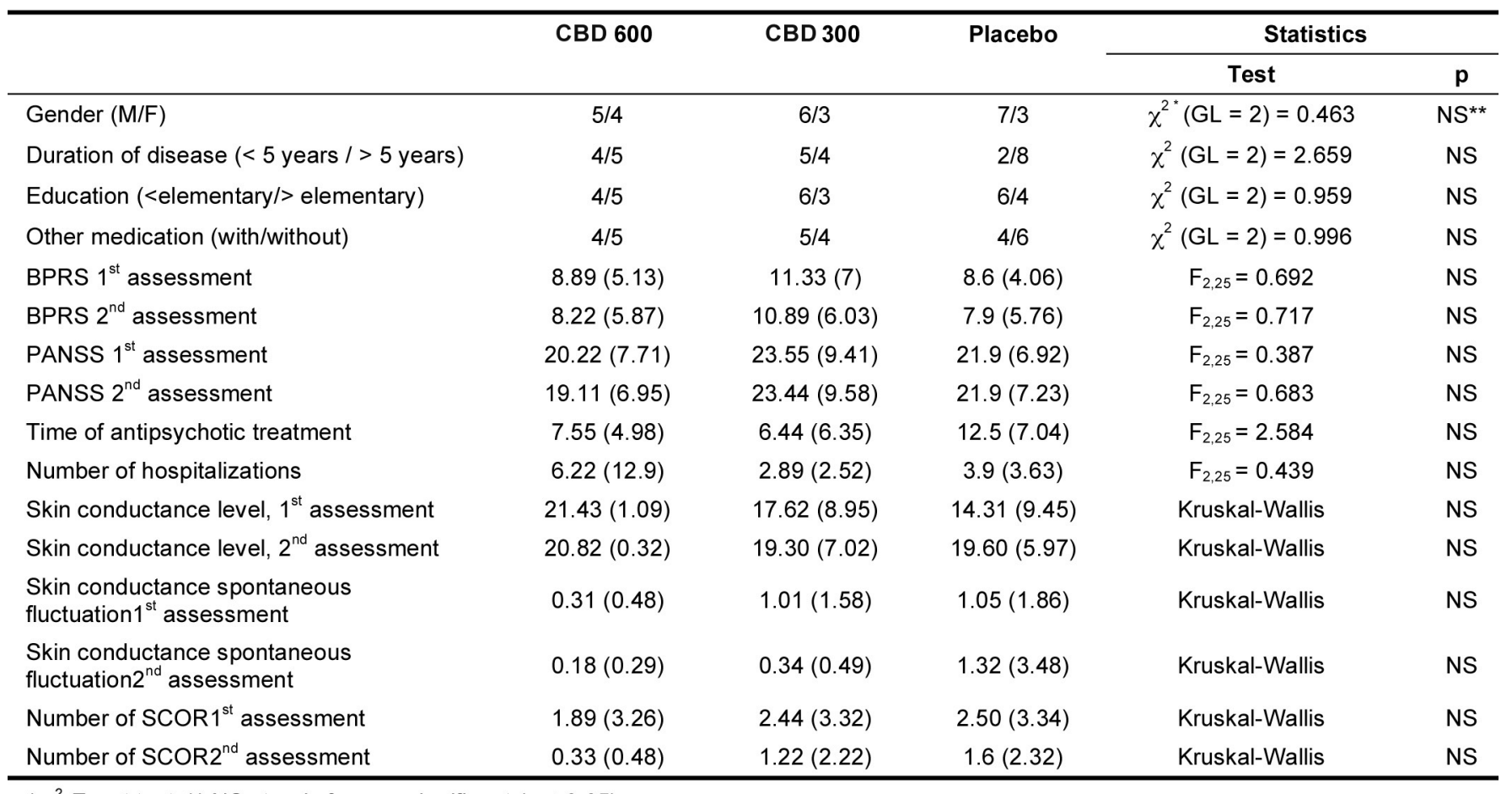

${ }^{*} \chi^{2}$ Exact test; ${ }^{* *} N S$ stands for non-significant $(p \leq 0.05)$

\section{Discussion}

The three groups were comparable regarding the clinical and demographic characteristics as well as the electrodermal responsiveness and SCWT performances evaluated in the first session. The longer time taken to complete board I by the nonresponsive schizophrenia patients in the first session could be related to processing speed, since this function is engaged by board I of the Stroop test. ${ }^{24}$ This difference related to electrodermal responsiveness was not maintained in the second session, probably due to a learning effect.

The main finding of this study concerns the number of errors on board II of the SCWT. The participants' performance improved from the first to the second session in terms of the errors committed. This difference was statistically significant for the placebo and CBD 300mg groups, although it was smaller and had a tendency to statistical significance in the CBD 600mg group.

The fact that the patients from all three groups improved in terms of the number of errors suggests a learning effect, with the possible development of strategies. These findings contrast with those by Chen et al., ${ }^{33}$ who found stable performance in patients with schizophrenia over time, although a direct comparison cannot be made since those authors used a computer-based version of the SCWT and differences have been reported between the performance in the card and computer versions of the test. ${ }^{34}$ The results of the card version of the SCWT may stem from a series of factors (the need to sustain visual scanpath and to ignore a series of surrounding distracting effects, item by item and column by column choice, and selection of one stimulus in a series of stimuli) which allow for the development of strategies. ${ }^{35}$
The worse performance of the patients receiving CBD 600 $\mathrm{mg}$ in relation to those receiving placebo or CBD $300 \mathrm{mg}$ could be due to the compound's sedative effect, decreasing attention. Monti found that the acute administration of CBD has a shortlasting hypnotic effect in rats. ${ }^{36}$ Pickens, in a study with mice, demonstrated CBD's efficacy as a sedative agent in doses ranging between $1 \mathrm{mg} / \mathrm{kg}$ and $20 \mathrm{mg} / \mathrm{kg} .{ }^{37}$ Hypnotic effects of CBD have also been reported ${ }^{21}$ in healthy volunteers (at 600 , but not $300 \mathrm{mg}$ ) and patients with insomnia. ${ }^{38}$

The results of this experiment do not support the hypothesis that CBD leads to cognitive improvement as assessed with the SCWT. This notion is based on the fact that CB1 agonists were shown to have a negative action on cognitive measures; for instance, in learning and working memory, both in man and animals. ${ }^{39}$ According to these findings, some investigators suspected that a dysfunction in the cannabinoid system could be involved in the genesis of schizophrenia and in the disorder's characteristic cognitive deterioration, which would enable the development of novel pharmacological approaches.

This action on cognitive function is probably largely due to the pattern of distribution of CB1 receptors in the brain, particularly in the substantia nigra, basal ganglia, cerebellum, and hippocampus. ${ }^{39}$ The high concentration of cannabinoid receptors in the hippocampus strongly suggests that the cannabinoid system is involved in superior cognitive functioning. ${ }^{8}$ Thus, it could be expected that cannabinoid antagonist compounds would be able to improve cognitive performance. In spite of its low affinity for $\mathrm{CB} 1$ and $\mathrm{CB} 2$ receptors, experimental evidence has shown that $\mathrm{CBD}$ is capable of antagonizing $\mathrm{CB} 1 / \mathrm{CB} 2$ receptor agonists at reasonably low concentrations. ${ }^{40}$ Thus an action could be expected from it in the sense of improving the performance of schizophrenic patients in the SCWT. 
BOARD II

NUMBER OF ERRORS

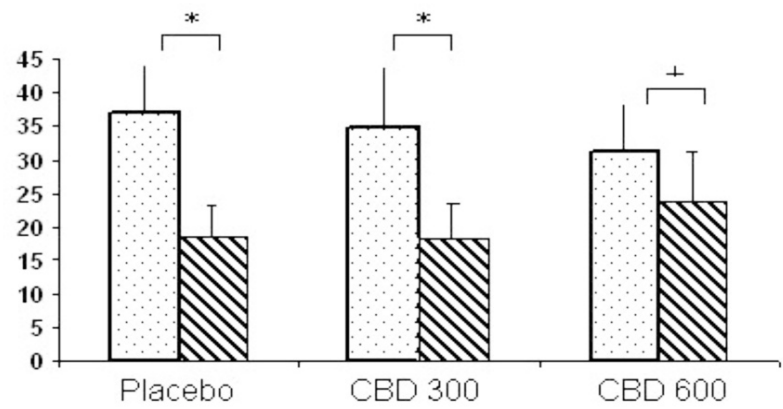

Figure 1 - Mean number of errors in the SCWT for each group in each experimental session. Dotted columns represent mean errors in session I, striped columns refer to session II. Vertical bars stand for standard-error. The positive (+) sign indicates tendency to statistical significance $(p<0.1)$.

* indicates statistical significance with $p<0.05$.
This study has some limitations, including the relatively short time between the two sessions (one month), which could induce interference of learning, and the use of only one test of cognitive functioning.

The non-confirmation of the hypothesis posed above by using a single dose of CBD does not exclude the possibility that the chronic use may lead to the expected cognitive improvement, as happens with clozapine, which requires a period of adaptation to its sedative effect before its therapeutic action can be observed.

\section{Acknowledgements}

The study was supported in part by grants from Conselho Nacional de Desenvolvimento Científico e Tecnológico (CNPq) and Fundação de Amparo à Pesquisa do Estado de São Paulo (FAPESP).

\section{Disclosures}

\begin{tabular}{|c|c|c|c|c|c|c|c|}
\hline $\begin{array}{l}\text { Writting group } \\
\text { member }\end{array}$ & Employment & $\begin{array}{l}\text { Research } \\
\text { grant }^{1}\end{array}$ & $\begin{array}{c}\text { Other research grant } \\
\text { or medical continuous } \\
\text { education }^{2}\end{array}$ & $\begin{array}{l}\text { Speaker's } \\
\text { honoraria }\end{array}$ & $\begin{array}{l}\text { Ownership } \\
\text { interest }\end{array}$ & $\begin{array}{l}\text { Consultant/ } \\
\text { Advisory } \\
\text { board }\end{array}$ & Other $^{3}$ \\
\hline $\begin{array}{l}\text { Jaime Eduardo } \\
\text { Cecílio Hallak }\end{array}$ & FMRP/USP & $\begin{array}{l}\text { CNPq } \\
\text { FAPESP } \\
\text { FAEPA }\end{array}$ & - & - & - & - & - \\
\hline $\begin{array}{l}\text { João Paulo } \\
\text { Machado-de- } \\
\text { Sousa }\end{array}$ & FMRP/USP & $\begin{array}{l}\text { CNPq } \\
\text { FAPESP } \\
\text { FAEPA }\end{array}$ & - & - & - & - & - \\
\hline $\begin{array}{l}\text { José Alexandre } \\
\text { S. Crippa }\end{array}$ & FMRP/USP & $\begin{array}{l}\text { CNPq } \\
\text { FAPESP } \\
\text { FAEPA }\end{array}$ & - & - & - & - & - \\
\hline $\begin{array}{l}\text { Rafael Faria } \\
\text { Sanches }\end{array}$ & FMRP/USP & $\begin{array}{l}\text { CNPq } \\
\text { FAPESP } \\
\text { FAEPA }\end{array}$ & - & - & - & - & - \\
\hline $\begin{array}{l}\text { Clarissa } \\
\text { Trzesniak }\end{array}$ & FMRP/USP & $\begin{array}{l}\text { CNPq } \\
\text { FAPESP } \\
\text { FAEPA }\end{array}$ & - & - & - & - & - \\
\hline $\begin{array}{l}\text { Cristiano } \\
\text { Chaves }\end{array}$ & FMRP/USP & $\begin{array}{l}\text { CNPq } \\
\text { FAPESP } \\
\text { FAEPA }\end{array}$ & - & - & - & - & - \\
\hline $\begin{array}{l}\text { Sandra } \\
\text { Aparecida } \\
\text { Bernardo }\end{array}$ & FMRP/USP & $\begin{array}{l}\text { CNPq } \\
\text { FAPESP } \\
\text { FAEPA }\end{array}$ & - & - & - & - & - \\
\hline $\begin{array}{l}\text { Simone Cecílio } \\
\text { Regalo }\end{array}$ & FMRP/USP & $\begin{array}{l}\text { CNPq } \\
\text { FAPESP } \\
\text { FAEPA }\end{array}$ & - & - & - & - & - \\
\hline $\begin{array}{l}\text { Antonio Waldo } \\
\text { Zuardi }\end{array}$ & FMRP/USP & $\begin{array}{l}\text { CNPq } \\
\text { FAPESP } \\
\text { FAEPA }\end{array}$ & - & - & - & - & - \\
\hline
\end{tabular}

* Modest

** Significant

*** Significant. Amounts given to the author's institution or to a colleague for research in which the author has participation, not directly to the author. Note: FMRPIUSP = Faculdade de Medicina de Ribeirão Preto, Universidade de São Paulo; CNPq = Conselho Nacional de Desenvolvimento Científico e Tecnológico; FAPESP = Fundação de Amparo à Pesquisa do Estado de São Paulo; FAEPA = Fundação de Apoio ao Ensino, Pesquisa e Assistência do Hospital das Clínicas da Faculdade de Medicina de Ribeirão Preto da Universidade de São Paulo.

For more information, see Instructions for authors. 


\section{References}

1. Moreau J. Hashish and Mental Illness. New York (NY): Raven Press; 1973.

2. Devane WA, Dysarz FA, Johnson MR, Melvin LS, Howlett AC. Determination and characterization of a cannabinoid receptor in rat brain. Mol Pharmacol. 1988;34(5):605-13.

3. Ashton $\mathrm{CH}$. Pharmacology and effects of cannabis: a brief review. Br J Psychiatry. 2001;178:101-6.

4. Devane WA, Hanus L, Breuer A, Pertwee RG, Stevenson LA, Griffin G, Gibson D, Mandelbaum A, Etinger A, Mechoulam R. Isolation and structure of a brain constituent that binds to the cannabinoid receptor. Science. 1992;258(5090):1946-9.

5. Kovasznay B, Fleisher J, Tanenberg-Karant M, Miller AD, Bromet E. Substance use disorder and the early course of illness in schizophrenia and affective psychosis. Schizophr Bull. 1997;23(2):195-201.

6. Andréasson S, Allebeck P, Engström A, Rydberg U. Cannabis and schizophrenia. A longitudinal study of Swedish conscripts. Lancet. 1987;2(8574):14836.

7. Leweke FM, Giuffrida A, Wurster U, Emrich HM, Piomelli D. Elevated endogenous cannabinoids in schizophrenia. Neuroreport. 1999;10(8):1665-9.

8. Emrich HM, Leweke FM, Schneider U. Towards a cannabinoid hypothesis of schizophrenia: Cognitive impairments due to dysregulation of the endogenous cannabinoid system. Pharmacol Biochem Behav. 1997;56(4):803-7.

9. Glass M. The role of cannabinoids in neurodegenerative diseases. Prog Neuropsychopharmacol Biol Psychiatry. 2001;25(4):743-65.

10. Leweke FM, Koethe D. Cannabis and psychiatric disorders: it is not only addiction. Addict Biol. 2008;13(2):264-75.

11. Karniol IG, Carlini EA. Pharmacological interaction between cannabidiol and delta 9-tetrahydrocannabinol. Psychopharmacologia. 1973;33(1):53-70.

12. Zuardi AW, Shirakawa I, Finkelfarb E, Karniol IG. Action of cannabidiol on the anxiety and others effects produced by delta 9-THC in normal subjects. Psychopharmacology (Berl). 1982;76(3):245-50.

13. Zuardi AW, Teixeira NA, Karniol IG. Pharmacological interaction of the effects of delta 9-tetrahydrocannabinol and cannabidiol on serum corticosterone levels in rats. Arch Int Pharmacodyn Ther. 1984;269(1):12-9.

14. Zuardi AW, Antunes-Rodrigues J, Cunha JM. Effects of cannabidiol in animal models predictive of antipsychotic activity. Psychopharmacology. 1991;104(2):260-4.

15. Leweke FM, Schneider U, Radwan M, Schmidt E, Emrich HM. Different effects of nabilone and cannabidiol on binocular depth inversion in man. Pharmacol Biochem Behav. 2000;66(1):175-81.

16. Zuardi AW, Crippa JAS, Hallak JEC, Moreira FA, Guimarães FS. Cannabidiol as an antipsychotic drug. Braz J Med Biol Res. 2006;39:421-9.

17. Zuardi AW, Morais SL, Guimarães FS, Mechoulam R. Antipsychotic effect of cannabidiol. J Clin Psychiatry. 1995;56(10):485-6.

18. Leweke FM, Koethe D, Gerth CW, Nolden BM, Schreiber D, Gross S, Schultze-Lutter F, Hellmich M, Klosterkotter J. Cannabidiol as an antipsychotic agent. 2005 Symposium on the Cannabinoids. Eur Psychiatry. 2007;22(Suppl 1):S21.

19. Zuardi AW, Guimarães FS, Guimarães VNC, Delben EA. Cannabidiol. In: Grotenhermen F, editor. Cannabis und Cannabinoide. Bern: Verlag Hans Huber; 2001. p.381-93.

20. Carter CS, Mintum M, Nichols T, Cohen JD. Anterior cingulate gyrus disfunction and selective deficits in schizophrenia: $[15 \mathrm{O}] \mathrm{H} 2 \mathrm{O}$ PET study during single-trial Stroop task performance. Am J Psychiatry. 1997;154(12):1670-5.

21. Hyman SE, Fenton WS. What are the right targets for psychopharmacology? Science. 2003;299(5605):358-9.

22. Green MF, Nuechterlein KH. Should schizophrenia be treated as a neurocognitive disorder? Schizophr Bull. 1999;25(2):309-19.

23. Grapperon J, Delage M. Stroop test and schizophrenia. Encephale. 1999;25(1):50-8.

24. Crippa, JAS, Hallak JEC, Sanches RF, Lopes-Machado EZL, Guimarães FS, Heten LA, Zuardi AW. Alteraçōes eletrodérmicas na esquizofrênia. J Bras Psiquiatr. 2001;50(7-8):255-64.

25. Lopes-Machado EZ, Crippa JA, Hallak JE, Guimarães FS, Zuardi AW. Electrodermically nonresponsive schizophrenia patients make more errors in the Stroop Color Word Test, indicating selective attention deficit. Schizophr Bull. 2002;28(3):459-66.
26. First MB, Spitzer RL, Gibbon M, Williams JB. Structured clinical interview for DSM-IV axis I disorders - clinician version (SCID-CV). Washington (DC): American Psychiatric Press; 1997.

27. Overall JE, Gorham DR. The brief psychiatric rating scale. Psycol Rep. 1962;10:799-812.

28. Kay SR, Fiszbein A, Opler LA. The positive and negative syndrome scale (PANSS) for schizophrenia. Schizophr Bull. 1987;13:261-76.

29. Liddle PF, Morris D. Schizophrenic syndromes and frontal lobe performance. Br J Psychiatry. 1991;158:340-5.

30. Chaves AC, Shirakava I. Escala das síndromes negativa e positiva - PANSS e seu uso no Brasil. Rev Psiquiatr Clin. 1998;25:337-43.

31. Bernstein AS, Frith CH, Gruzelier JH, Patterson T, Straube E, Venables PH, Zahn TP. An analysis of the skin conductance orienting response in samples of American, British, and German schizophrenics. Biol Psychol. 1982;14(3-4):155-211.

32. Dawson ME, Nuechterlein KH, Schell AM, Gitlin M, Ventura J. Autonomic abnormalities in schizophrenia - State or trait indicators? Arch Gen Psychiatry. 1994;51:813-24.

33. Chen EYH, Wong AWS, Chen RYL, Au JWY. Stroop interference and facilitation effects in first-episode schizophrenic patients. Schizophr Res. 2001;48(1):29-44.

34. Baxter RD, Liddle PF. Neuropsychological deficits associated with schizophrenic syndromes. Schizophr Res. 1998;30(3):239-49.

35. Perlstein WM, Carter CS, Barch DM, Baird JW. The Stroop task and attention deficits in schizophrenia: a critical evaluation of card and single-trial Stroop methodologies. Neuropsychology. 1998;12(3):414-25.

36. Monti JM. Hypnotic-like effects of cannabidiol in the rats. Psychopharmacology (Berl). 1977;55(3):263-5.

37. Pickens JT. Sedative activity of cannabis in relation to its $\Delta 9$-tetrahydrocannabinol and cannabidiol content. Br J Pharmacol. 1981;72(4):649-56.

38. Carlini EA, Masur J, Magalhães CCPB. Possível efeito hipnótico do canabidiol no ser humano. Estudo preliminar. Ciênc Cult (São Paulo). 1979;31:31522.

39. Brodkin J, Moerschbaecher, JM. SR141716 antagonizes the disruptive effects of cannabinoid ligands on learning in rats. J Pharmacol Exp Ther. 1997;282(3):1526-32.

40. Thomas BF, Gilliam AF, Burcj DF, Roche MJ, Setzman HH. Comparative receptor binding analyses of cannabinoid agonists and antagonists. $J$ Pharmacol Exp Ther. 1998;285(1):285-92. 